\title{
Guidelines for identifying risk vulnerabilities associated with ICT sourcing
}

\author{
A.Cachia \\ Department of Informatics, University of Pretoria \\ Pretoria 0002, Republic of South Africa \\ yogiadelle@yahoo.com \\ C.J. Kruger* \\ Department of Informatics, University of Pretoria \\ Pretoria 0002, Republic of South Africa \\ Neels kruger@up.ac.za
}

Received October 2007

\begin{abstract}
As organizations broaden their organizational boundaries with sourcing practices, it is imperative to identify risk vulnerabilities from a wider perspective than before. Specifically, organizations that make substantial use of ICT suppliers need to understand the risk vulnerabilities associated with ICT sourcing partnerships. Unfortunately, due to vulnerabilities being addressed from different levels of erudition, an inclusive list of risk vulnerabilities, associated with ICT suppliers, does not exist within the ICT industry. This article not only address ICT risk management discrepancies and the importance of ICT supplier management, but in drawing on the collective knowledge contained in diverse sources, two distinct lists containing risk vulnerabilities, from the customer organization's perspective, are generated, all, in order to accelerate the understanding of exposure when dealing with ICT suppliers.
\end{abstract}

*To whom all correspondence should be addressed.

\section{Introduction}

After the September $11^{\text {th }} 2001$ terrorist attack in the USA, risk management received renewed attention as a means of avoiding being placed in jeopardy by an event that might seem unlikely, impossible or even incomprehensible (Anderson, 2001). That tragic event sounded alarm bells for many organizations about the necessity not only to consciously manage risk, but also to be in a position to identify and understand vulnerabilities ${ }^{1}$ with regard to risk.

According to the King Report (Institute of Directors, 2002), ICT has had a major impact on the way business is conducted, especially with traditional value chains disintegrating and organizational boundaries becoming blurred. Hunter and Bloch (2003) argues that due to the shift in the importance of ICT, stakeholders should not only understand what constitutes ICT risks, but also need reassurance that ICT risks are managed in an effective and efficient manner. As far back as 1998, Leenders and Blenkhorn argued that ensuring successful technological risk management necessitates a strong focus on supplier relationships. Porter (2001) concurs with this idea, maintaining that few (if any) organizations are totally selfsufficient, relying on suppliers to optimize their value

${ }^{1} \mathrm{~A}$ vulnerability is a weakness that exposes an organization to hurt, harm or attack and enables the risk to have impact. (Oxford, Kliem 1999). chains. Du Rand (2003) agrees, adding that Information Technology Organizations (ITOs) depend on suppliers to provide technology services and assist in managing technology risks. ICT risks therefore need to be managed across the entire supply chain, from suppliers to customers, placing special emphasis on the transition from ICT suppliers and Outsource Partners to the Internal IT Organisation, Support Divisions and/or Line of Business.

In agreement with the King Report (Institute of Directors, 2002: 81) recommending ${ }^{2}$ that organizations develop a 'demonstrable system of dynamic risk identification as part of their risk management strategy', Naidoo (2002) asserts that the days of intuitive risk management are over and suggests that in future any such endeavours will be considered poor corporate governance practice. Due to ICT risk management becoming a legal matter, rather than just a managerial necessity, Clemons (2003), at a conference on strategic sourcing, asked whether there are any support and monitoring systems available to manage risk and rewards with regard to strategic ICT sourcing.

Coles and Moulton (2003) points out that as a rule, traditional ICT risk assessment is approached from within a systems or a business process methodology. Most risk assessment models, for example those in use by KPMG,

\footnotetext{
${ }^{2}$ This recommendation is for a system of risk management and internal control of which dynamic risk identification is one mechanism.
} 
Cobit and others, therefore consider risk in its totality and do not provide specific guidelines for the identification of risk vulnerabilities associated with sourcing, supplier organizations or supplier relationships. Unfortunately this leaves the organization with a biased view of risk, especially with regard to sourcing and supplier vulnerabilities, complicating the formulation of a combined risk strategy.

Vulnerabilities associated with supplier relationships are not new and many clues, hints and points of advice are available from numerous disparate sources, for example project management practices, capability maturity models, software development, project sourcing, outsourcing, etc. However, these are typically employed in an ad hoc manner on an operational or tactical level, and not synergised to give a broader, comprehensive view of only those vulnerabilities associated with suppliers. In the quest to identify ICT sourcing and supplier vulnerabilities, Anderson (2001) argues that it might be possible to instinctively identify many of these vulnerabilities from within the perspective of ITOs, especially when supplier relationships are actively managed with open communications and information sharing.

The aim of the article is therefore to generate guidelines for the identification of risk vulnerabilities, from a customer organization's perspective, in order to accelerate understanding of possible exposure when dealing with ICT suppliers. This study includes an analysis of an ITO where ICT is considered to be an integral part of the business. The proposed guidelines are not necessarily exhaustive, but they do collate suggestions scattered across a number of disparate sources - suggestions which, when viewed in a holistic manner, render one capable of identifying the most important risk vulnerabilities associated with ICT sourcing.

In order to achieve the above-mentioned objective, the scope of the research covers the following topics:

- $\quad$ The importance of ICT supplier management

- $\quad$ ICT Risk Management discrepancies

- $\quad$ ICT risk vulnerabilities identified in literature

- $\quad$ ICT risk vulnerabilities identified in the case study.

The article ends with a short summary of the primary findings.

\section{Methodology}

The research scope was limited to two areas expounded upon in the ICT environment, namely supplier management and risk management. The substantial literature review drawn from accredited academic journals, accepted industry best practice, commercial research institutions and media articles introduces work already done on the abovementioned topics, thus confirming the pertinence of the topic. Analysis of the literature (exploratory research) led to the identification of a generic list of ICT risk vulnerabilities. However, since organizations across the world do not as a rule publish or make available all vulnerabilities, the validity of using only a literature review to formulate an inclusive list of risk vulnerabilities was questioned ${ }^{3}$. Moreover, in order to adhere to the principle proposed by Anderson (2001) 'that it might be possible to instinctively identify many ICT vulnerabilities from within the perspective of ITOs', further insight was sought through harvesting vulnerabilities instinctively identified by an ITO. Unfortunately, information used to manage suppliers is for the most part considered confidential by companies, and therefore any elaboration on information contained in company-confidential documentation was minimised as far as possible to include only the gist of arguments proposed and/or lessons learned. Similarly, opinions expressed by interviewees were only included when they added new insight to the line of reasoning. At all times company sources were treated as extremely confidential. Although this placed a limitation on the value of the study, the authors are of the belief that when viewed holistically, the case study provided enough insight to enhance the literature findings.

The organization chosen for the case study forms part of the financial services industry (including banking) with wellestablished e-business channels. Technology plays a strategic role in the organization and is managed by a large and mature ITO that provides traditional and inventive ICT services to the organization. The ITO has been practising supplier management for over three years and has collected valuable and unique information during this time. Previously unknown data was therefore collected using its supplier relationship management tool developed in-house to form a supplier management model, as well as minutes of meetings and periodic supplier evaluations. ICT supplier risk vulnerabilities were deduced from these sources and organized in the same categories as the list developed from ICT industry sources (i.e. the literature review). Via structured in-depth personal interviews with senior ITO participants $^{4}$ involved in managing key ICT supplier relationships, risk vulnerabilities were further scrutinized to try and identify the most applicable ones. In matching and comparing the vulnerabilities identified in literature with the vulnerabilities identified in the case study ${ }^{5}$, valuable insight was gained into the management of ICT supplier risk vulnerabilities. The research method followed thus formed the basis for a grounded theory approach, consisting of three phases namely (1) identifying research areas of focus, (2) deciding on the most appropriate research design and (3) elaborating on research results (refer to Figure 1: Research Methodology).

\footnotetext{
${ }^{3}$ According to Yin (2003), given the complex nature of supplier relationships and the unique management thereof, the sources and nature of many ICT supplier vulnerabilities are only identifiable through confidential sharing of strategic information.

${ }^{4}$ In total 8 structured interviews were conducted.

${ }^{5}$ Confidential source list consists of 146 documents.
} 


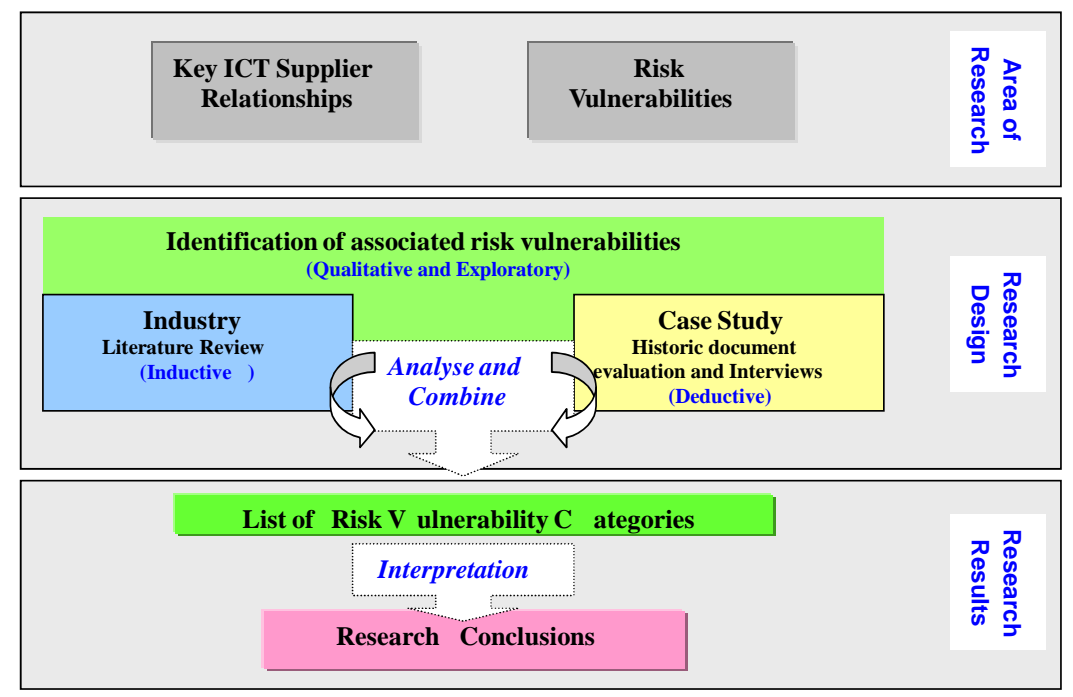

Figure 1: Research methodology

\section{ICT Risk Management discrepancies}

Deloach (2001) is of the opinion that current assumptions about and approaches to assessing risks may no longer be appropriate. This is primarily due to risks previously thought of as impossible, now becoming a reality. Deloach therefore advises organizations to refine their risk management approach to cost-effective and strategic risk management activities by developing capabilities to aggregate risk information to evaluate the risk in the organisation more broadly, i.e. also to identify vulnerabilities. The King Report (Institute of Directors, 2002:97) describes Risk Management as being '...the identification and evaluation of actual and potential risk areas (therefore also vulnerabilities) as they pertain to the company as a total entity, followed by a process of either termination, transfer, acceptance (tolerance) or mitigation of each risk'. In a similar manner, Suh and Han (2002) describe the purpose of risk management as an effort to minimise expected loss, and risk analysis as the basis on which (these) risk decisions should be made.

Recently, although not specifically focusing on ICT, the Committee of Sponsoring Organizations of the Treadway Commission (COSO, 2003) provided practical guidance to assist an organisation in building effective programmes to identify, measure, prioritize and respond to risks. Of interest is the fact that the framework, like the King Report (Institute of Directors, 2002), includes the identification of vulnerabilities and suggests that risks need to be identified in internal and external factors. Internal factors proposed are infrastructure, personnel, process and technology, while external factors are believed to comprise economic, business, natural environment, political, social and technological matters. In order to control and manage risk, the COSO framework encourages the identification of what they consider to be 'risk events'. In essence, according to the COSA framework, a risk event (RE) occurs when a threat (T) exploits a risk vulnerability (V).

A risk event (RE) occurs when a threat $(\mathrm{T})$ exploits a risk vulnerability (V),

thus

$\mathrm{T}+\mathrm{V}=\mathrm{RE}$

With regards to ICT Risk management, the high rate of development and obsolescence in ICT makes decisions on ICT expenditure particularly difficult. Traditionally, management was not able to apply cost/value principles to ICT as easily as in other areas of business. This led to the perception that ICT expenditure is motivated by strategic instinct rather than sound commercial principles. According to Coles and Moulton (2003), traditional ICT risk analysis methodologies therefore wrongly focus on addressing only the possible impact on operations and systems. Risk management models, for example the KPMG IT risk management assessment model, are therefore not holistic in nature, only assessing risk from an internal point of view, and/or assuming that supplier risks are addressed when various risk categories, e.g. reliability, business focus, IT skills and resources, etc., are evaluated. In a similar manner, risk assessment and managerial tools, as listed by the Institute of Internal Auditors (1998), do not specifically supply detail with regard to identifying vulnerabilities associated with ICT suppliers.

\section{The importance of ICT supplier management}

According to Ford (1998), changes in the ICT industry, global economic slowdown, as well as local and international regulatory requirements, are all altering the ICT supplier management landscape. Ford is of the opinion 
that these changes are raising the risk stakes, pushing supplier management to a strategic level. Fernandez (1995) earlier described the characteristics of a strategic supplier relationship as commitment to partnership, early involvement in decision making, mutual trust and crisis management. In agreement with Fernandez, Ford (1998) describes strategic relationships as substantial and maintains that it is not easy to change them quickly without incurring significant costs both in terms of disruptions and developing new relationships. Ford therefore asserts that strategic relationships are important assets and without them organisations cannot operate or even exist. He adds that an organization's performance does not only depend on its own actions and wishes, especially when interdependencies are present. Hutt, Stafford, Walker and Reingen (2000) supports this thinking, stating that both communication and the pro-active exchange of information strengthen relationships. In similar vein, Leonard (2000) argues that building and maintaining a sound relationship creates alignment between parties. Lacity (2002) adds yet another dimension to the line of reasoning by arguing that collaborative interactions occur when both sides share similar goals and comments. However, Lacity stresses the fact that the best relationships embrace mutual dynamics, with each party aiming for fairness, not domination or exploitation. Cooray and Ratnatunga (2002) also believes that through relationship management, successful long-term relationships can be developed despite substantial differences between firms. Melymuka (2003) concurs, and argues that even though not all suppliers have the same importance to an organization, supplier management (and the risks associated with it) is now becoming a core competency.

\section{ICT risk vulnerabilities identified in literature}

The quest to identify a holistic list of risk vulnerabilities associated with ICT sourcing, led to the identification of a number of holistic categories ${ }^{6}$ in literature (refer to Table 1 and Appendix A: ICT supplier vulnerabilities identified in literature). The section that follows is a summary of vulnerability categories, as presented in appendix A.

The Cobit guidelines, Cosgroe (2003), Lehman (2003), Berinato (2004), Kliem (1999), Kern, Willcocks and Lacity (2002) and KPMG (2000 and 2003) all agree that in an attempt to minimize risks, formal supplier contracts need to be entered into. All these sources warn of typical flaws when contracts are poorly formulated and/or badly understood and managed. Some vulnerabilities were identified that specifically relate to service contracts and the management thereof, for example Service Level Agreements (SLAs) not in place or not agreed upon, only technical metrics, undefined procedures, etc. Lacity (2002) describes numerous vulnerabilities in her discussion of ICT outsourcers, putting forward the theory that the very nature of outsourcing agreements and their formalization in legal contracts creates risk. Lacity also maintains that poor understanding of the organization's ICT portfolio propagates poor vendor practices, thereby increasing risk. Watkins and Bazerman (2003) asserts that suppliers should be chosen and managed objectively and not on the basis of personal relationships. Watkins also believes that good communications counter vulnerability between the contracting parties and soften internal organizational obstacles, e.g. silos create risk vulnerabilities.

Lehmann (2003 (Part 1)) expresses concern about defective monitoring of actual service delivery, while Kliem (1999) highlights the notion that risk vulnerability might also be seated in the inappropriate reporting of delivered services. Cobit (IT Governance Institute 2002) agrees that both these service delivery issues need to be controlled. In addition, Lacity (2002) mentions poor availability and reliability of systems and the Internet from service providers, which might hurt business performance. Cosgroe (2003) and Desmond (2003) state that purchasing inappropriate or poor quality software makes the organization vulnerable to further ICT expenses. Coles and Moulton (2003) confirms that some of these vulnerabilities might be the result of an inherent flaw in the software product, e.g. poor security.

Lehmann (2003 (Part 1)), supported by Mphasis (2002), is concerned about the factors that influence a supplier, for example merger and acquisitions, and lawsuits that spill over to affect the organization. According to Mphasis (2002), suppliers' ability to survive is influenced by a number of market factors, forces that can expose an organization's supply chain. Steenstrup et al (2003) and Lehmann (2003a and b) agree, adding that financial health factors might also pose a threat to the supplier's ability to survive. Cobit in IT Governance Institute (2002) and the King Report (Institute of Directors, 2002) are more specific about suppliers' non-compliance with legal and regulatory requirements, which might expose the organization, for example insider trading. Naidoo (2002) adds that suppliers can possibly use confidential organizational or client information illicitly.

The King Report, together with others (Lehmann, 2003; Siegil, 1996; Cosgroe, 2003; Mphasis, 2002; Goodwin, 2003; and Kern et al., 2002), all stress that when suppliers do not disclose or share important internal information with the organization, this leaves the organization vulnerable to poor service, for example poorly selected sub-contractors, high percentage of inexperienced personnel, etc. Varon (2003) also points out that vendors cannot respond well to risks if they under-price. Throughout the literature on the subject it is therefore evident that poor relationships form a breeding ground for vulnerabilities. Kern et al. (2002) and Ford (1998), supported by the Software Engineering Institute (SEI). 2003 and Cobit (IT Governance Institute, 2002), therefore contend that relationships need to be nurtured and not only managed.

\footnotetext{
${ }^{6}$ It became apparent that in general a vast number of vulnerability dimensions tend to complement one another. Dimensions were therefore placed in logical groupings (categories) to provide the structure for further comparison and analysis.
} 
Table 1: Risk vulnerabilities categories as identified from the literature review.

\begin{tabular}{l|l}
\hline Poor service agreements and management thereof & Insight into supplier's future survivability \\
\hline Poor contracts and management thereof & Undisclosed information of supplier internal operations \\
\hline Inappropriate and poor service delivery monitoring & Supplier's inappropriate solution/product or service offering \\
\hline Inappropriate and poor service delivery reporting & Supplier's lack of enterprise risk assessment \\
\hline High level of dependency on technology & Supplier's non-compliance with legal and regulatory requirements \\
\hline Poor supplier management practices & Supplier breaches confidentiality \\
\hline Implementing new or complex technology & Supplier's lack of service availability \& reliability \\
\hline Poor quality control in implementing and managing technology & Supplier's poor responsiveness to risk \\
\hline Not nurturing the quality of the relationship & Supplier's external organisational accountability \\
\hline Relationship yields low economic value & Supplier's product flaws \\
\hline Flawed outsourcing partnership/s & Large financial exposure on the part of supplier \\
\hline Poor communication between the parties & Supplier’s incompetent service delivery \\
\hline Awareness of supplier's financial stability/health & Supplier compromises its integrity \\
\hline
\end{tabular}

According to Ford, the implementation of new or complex technology also raises the risk stakes, for example if the supplier manipulates uncertainties. According to the Software Engineering Institute (SEI). 2003 and Cosgroe (2003), a high level of dependency on technology creates vulnerabilities relating to the dependency on a supplier.

\section{ICT risk vulnerabilities identified in the case study}

In order to adhere to the proposition put forward by Anderson (2001) that it might be possible to instinctively identify many ICT vulnerabilities from within the perspective of ITOs, and Yin's (2003) argument that the sources and nature of many ICT supplier vulnerabilities are only identifiable through confidential sharing of strategic information, further insight was sought through examining vulnerabilities instinctively identified by the ITO $^{7}$. Numerous risk vulnerabilities were identified in the case study documents (refer Appendix B: Case Study ICT Supplier Key Relationship Vulnerabilities). In matching the industry and case study lists of vulnerability dimensions, it was found that only $14 \%$ of vulnerability dimensions were exact matches (see Figure 2). This was primarily due to sources addressing vulnerabilities from either a strategic or a detailed (operational) perspective, especially with regard to the level of erudition.

Careful scrutiny of vulnerability dimensions from a holistic perspective, however, again confirmed the notion that vulnerability dimensions are in fact related. Viewing vulnerability dimensions as interdependent entities, i.e. vulnerability categories, therefore not only proved to be extremely valuable when it came to drawing comparisons between case study documents and literature findings, but

${ }^{7}$ Company A: 1999 - 2004. Various confidential documents relating to risk management and strategic supplier management were analysed. Confidential source list consisted of 146 documents. For legal and competitive reasons these documents are not publicly available and Company A confidential. also in guiding the structured interview process that followed (see Table 2).

Of interest is that although case study documents, like literature findings, place strong emphasis on vulnerabilities associated with flawed relationships, vulnerabilities caused by financial exposure, incompetence and integrity are also emphasized. In grouping vulnerability dimensions into vulnerability categories, three new categories could therefore be identified namely: (1) Large financial exposure on the part of the supplier, (2) Supplier incompetent service delivery and (3) Supplier compromises its integrity. The eight senior managers interviewed (participating in strategic ICT supplier management), not only confirmed that the vulnerability categories (as identified in the literature, and case study documents) are applicable and can definitely help organizations to successfully identify risk vulnerabilities associated with strategic ICT sourcing, but also provide practical insight into the successful management of ICT risk vulnerabilities. According to managers interviewed:

- 'Most vulnerabilities are within the organization's control and a small percentage are within the supplier's control'.

- 'Poor project management and internal control are the root causes of supplier vulnerabilities'.

- 'Be careful of "not authenticating vendor's sales hype" vs. the "true ability" to deliver'.

- $\quad$ 'Supplier management process must be end-to-end and not built around individuals (personalities)'. 


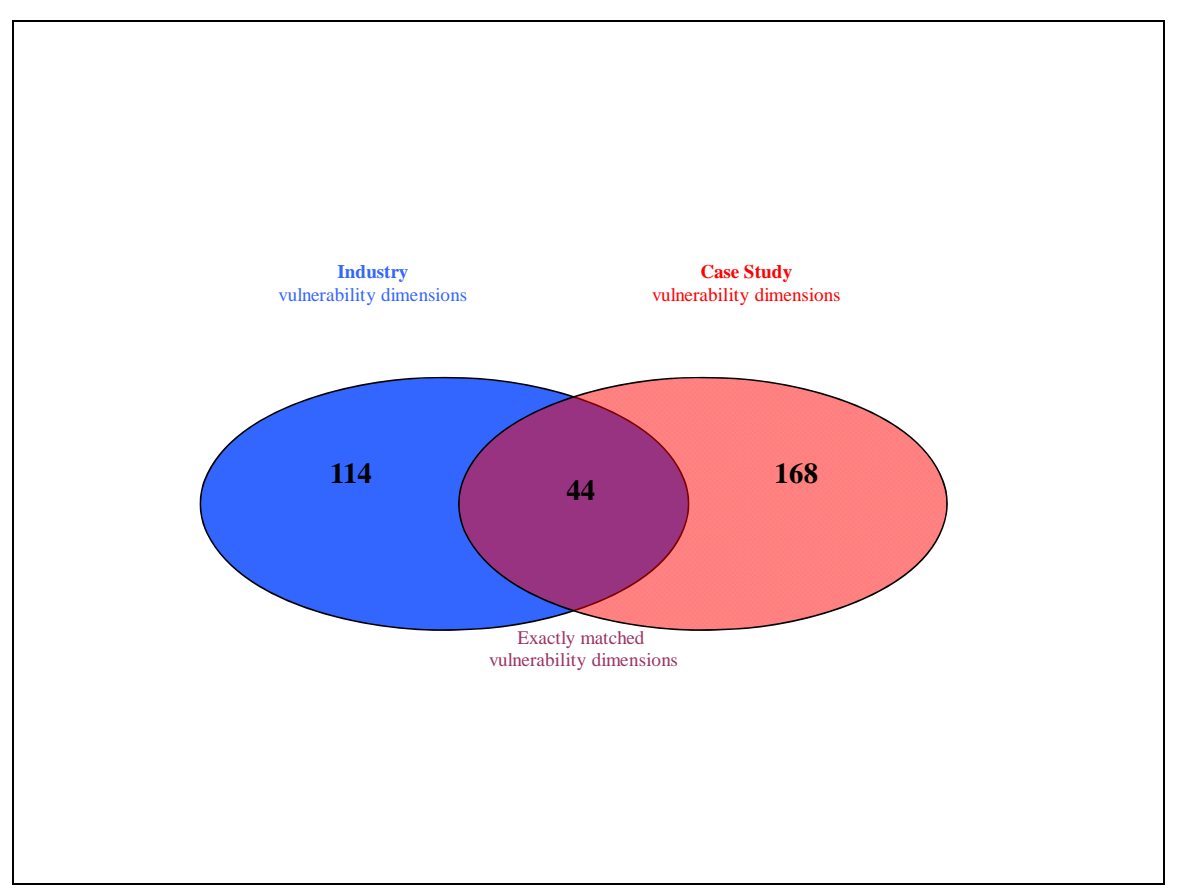

Fig 2: Exact matches of vulnerability dimensions

Table 2: Comparison between case study documents and literature findings

\begin{tabular}{|c|c|c|c|}
\hline Vulnerability category & $\begin{array}{l}\text { Literature } \\
\text { (\# found) }\end{array}$ & $\begin{array}{l}\text { Case Study } \\
\text { (\# found) }\end{array}$ & Frequency \\
\hline Poor service agreements and management thereof (7) & 9 & 14 & 23 \\
\hline Poor contracts and management thereof (1) & 15 & 24 & 39 \\
\hline Inappropriate and poor service delivery monitoring & 2 & 10 & 12 \\
\hline Inappropriate and poor service delivery reporting & 3 & 1 & 4 \\
\hline High level of dependency on a technology & 2 & 8 & 10 \\
\hline Poor supplier management practices & 4 & 8 & 12 \\
\hline Implementing new or complex technology & 2 & 5 & 7 \\
\hline Poor quality control in implementing and managing technology & 2 & 8 & 10 \\
\hline Not nurturing the quality of the relationship (3) & 9 & 21 & 30 \\
\hline Relationship yields low economic value (4) & 10 & 19 & 29 \\
\hline Flawed outsourcing partnership/s (2) & 25 & 7 & 32 \\
\hline Poor communication between the parties & 2 & 1 & 3 \\
\hline Awareness of supplier's financial stability/health (8) & 16 & 5 & 21 \\
\hline Insight into supplier's ability to survive in the future & 13 & 2 & 15 \\
\hline Undisclosed information about supplier’s internal operations (6) & 13 & 13 & 26 \\
\hline Supplier's inappropriate solution/product or service offering & 2 & 5 & 7 \\
\hline Supplier's lack of enterprise risk assessment (5) & 9 & 18 & 27 \\
\hline Supplier's non-compliance with legal and regulatory requirements & 1 & 7 & 8 \\
\hline Supplier breaches confidentiality & 1 & 1 & 2 \\
\hline Supplier's lack of service availability and reliability & 1 & 2 & 3 \\
\hline Supplier's poor responsiveness to risk & 2 & 5 & 7 \\
\hline Supplier's external organisational accountability & 5 & 3 & 8 \\
\hline Supplier’s product flaws & 1 & 5 & 6 \\
\hline Large financial exposure on the part of the supplier & 0 & 6 & 6 \\
\hline Supplier's incompetent service delivery & 0 & 8 & 8 \\
\hline Supplier compromises its integrity & 0 & 2 & 2 \\
\hline
\end{tabular}


- 'Be careful of manage-by-contract syndrome'. In predictable demand, exact contracting is possible, but with unpredictable demand, non-exact contracting must be done. Not all eventualities can be contracted for as contracts become difficult to manage or change'.

- $\quad$ 'Strategic relationships can create reciprocity that does not make business sense'.

- ‘An organization's image/reputation might be compromised when using a supplier that is not trusted in the market.'

- 'Appropriate criteria need to be considered in identifying strategic ICT relationships'.

With reference to Table 2, in analysing the frequency of occurrence $^{8}$, it became apparent that; (1) Poor contracts and the management thereof, (2) Flawed outsourcing partnerships, (3) Not nurturing the quality of the relationship, (4) Relationships yielding low economic value (5) Supplier's lack of enterprise risk assessment and (6) Undisclosed information about the supplier's internal operations can be considered the 'more important' risk vulnerability categories identified. However, even though senior managers interviewed all agreed that the different categories and vulnerability dimensions are all applicable, all rated the list of categories very differently and it seems that differences could be the result of the individual's experience, ability, skills and knowledge.

Most interviewees indicated that in viewing vulnerabilities from a holistic perspective, i.e. as interdependent vulnerability categories, the focus is primarily relegated to the managerial and tactical level. Although most interviewees indicated that this might be good practice, a number of interviewees argued that on a strategic level, (due to the economic impact on the organization, either in the long term or due to large financial investment), vulnerabilities categories need to be unbundled to expose concealed dimensions and risks. As an example, one participant pointed out that the vulnerability category 'Poor service level agreements and the management thereof' should typically be controlled on an operational level for a specific service that the supplier has agreed to provide. Project or functional control should thus be allocated to the manager who is accountable for the management of the SLA, problem solving and reporting. In a large ITO with many projects, functions and supplier SLAs, 'poor service level agreements and the management thereof' escalates to a strategic level when the service levels of a particular supplier are consistently inadequate and/or unreliable. The collective economic impact on the organization is therefore much larger than normally anticipated, and requires a higher or strategic-level focus and intervention. In other words the problem becomes a strategic relationship issue, where specifics, especially with regard to dimensional flaws, become paramount.

\footnotetext{
${ }^{8}$ Literature and case study company confidential documentation.
}

Most interviewees were also of the opinion that the organizations own information, practices, processes and procedures can control most vulnerabilities encountered. However, some interviewees stressed that it is those dimensions that are under the control of the supplier, or mutually controllable by both parties, that are the most tedious to manage. Interviewees therefore emphasised that vulnerabilities cannot be mitigated through influence, staying abreast and informed of the supplier's state of affairs and through collaboration alone. A robust relationship with suppliers is seen as a key success factor in identifying and influencing risk vulnerabilities. As one interviewee states 'organisations need to ensure that ICT supplier relationships are of a sound nature, and managed at a strategic level in order to lessen risk vulnerabilities escalating beyond the operational level, thus becoming a strategic concern'.

\section{Conclusion}

In this article it is argued that identifying risk vulnerabilities associated with ICT suppliers is becoming a legal necessity. Unfortunately, due to vulnerabilities being addressed from different levels of erudition, an inclusive list of risk vulnerabilities associated with ICT suppliers does not exist within the ICT industry. Drawing on the collective knowledge contained in diverse sources, the main thrust of the article is the formulation of two distinct lists of risk vulnerabilities, grouped into risk categories (appendixes A and B) associated with ICT suppliers. However, even though the knowledge contribution is specific in that it not only offers guidelines for identifying risk vulnerabilities associated with ICT sourcing, but also provides insight into risk identification, measures to combat risk vulnerabilities still need to be adapted to suit the specific needs of the individual organizations, and also the specific circumstances surrounding each and every risk vulnerability.

\section{References}

Anderson, M.F. 2001. 'Key risk considerations. Risk management'.[online] URL:

http://www riskmanagement.com.au. Accessed 7/11/2003.

Berinato, S. 2004. 'You sue, you lose: The high cost of litigation'. [online] URL:

http://www.cio.com/archive/020104/supplier.html. Accessed 20/2/2004.

BITS Advisory Council. 2004. 'BITS framework, financial services roundtable’. [online] URL: http://www.bitsinfo.org. Accessed 20/2/2004.

Blundell, D. 2003. 'Equip yourself to meet ECT legislation'. [online]URL:

http://www.enews.co.za/sections/QuickPrint/Print.asp?Story ID=136342. Accessed 10/5/2004.

Clemons, E.K. 2003. 'Understanding sourcing as a strategic business: The risks and rewards of strategic sourcing and inter-firm alliances'. Paper presented at The Wharton School, Strategic Sourcing Conference, Bangalore, 10 March 2003. 
Coles, S. \& Moulton, R. 2003. 'Operationalizing IT risk management’. Computers \& Security 22(6): 487-493.

Company A. 1999 - 2004. Various confidential documents relating to risk management and strategic supplier management. Results from 8 personal interviews with strategic Company A management. Confidential source list consists of 146 documents. ${ }^{9}$

Cooray, S. \& Ratnatunga, J. 2002. 'Buyer-supplier relationships: A case study of a Japanese and Western alliance', Long Range Planning 34(6): 727-740.

Cosgroe, L. 2003. 'Maximising value from IT vendors. Ware'. CIO research reports. [online] URL: http://www2.cio.com/research/surveyreport.cfm?id=65.

Accessed 12/11/2003.

Committee of Sponsoring Organizations of the Treadway Commission (COSO). 2003. 'Enterprise risk management framework-draft'. [online] URL: http://www.coso.org. Accessed 10/11/2003

Deloach, J. 2001. 'Enterprise risk management. Key risk considerations post September 11'. Reprinted as '2002-0110 key risk considerations', with permission from KnowledgeSpace Internal Audit and Risk Community - a subscription-based website sponsored by Anderson. [online] URL: http://www riskmanagement.com.au. Accessed $10 / 5 / 2004$

Deloitte. 2004. 'Global Banking Industry Outlook, 2004. Top ten issues, financial service industry'. [online] URL: www.deloitte.com. Accessed 11/7/2007.

Desmond, P. 2003. 'A better way to deal with vulnerabilities’. [online] URL:

http://itmanagement.earthweb.com. Accessed 11/7/2003.

Du Rand, L. 2003. 'Mastering the IT shuffle'. Computerweek Strategis, April: 37.

South Africa. 2002. 'Electronic Communications and Transactions (ECT) Act 25 of 2002', assented to 31 July 2002, commencement date 30 August 2002, p. 10.

Fernandez, R. R. 1995. Total quality in purchasing and supplier management. Delray Beach. Lucie Press.

Ford, D. 1998. Managing business relationships. England: John Wily \& Sons, Ltd.

Gordon, M. 2002, 'Everything's coming up suppliers!' $A B A$ Bank Compliance, 23(7): 4-130.

Goodwin, B. 2003. 'September attacks key driver for IT security investment, survey finds'. ComputerWeekly.com [online] URL: http://www.computerweekly.com articles. Accessed 7/11/2003.

\footnotetext{
${ }^{9}$ For legal and competitive reasons these documents are not publicly available and Company A confidential.
}

Hunter, R. \& Blosch, M. 2003. 'Managing the new IT risks', Gartner EXP CIO Signature [online] URL: http://www.commonperu.com/html/eventos/2006/cio/ppt/ga rtner/GARTNER_Applying_Enterprise_Architecture.pdf. Accessed 15/10/2006.

Hutt, M. D., Stafford, E. R., Walker, B. A. \& Reingen, P. H. 2000. 'Case study. Defining the social network of a strategic alliance', Sloan Management Review, 41(2): 5162.

Institute of Directors. 2002. King Report on corporate governance of South Africa 2002. Johannesburg. Centre of Directorship and Corporate Governance.

Institute of Internal Auditors. 1998. [online] URL: http://www.theiia.org. Accessed 10/11/2003.

IT Governance Institute. 2002. The COBIT framework DS1 delivery and support. Define and manage service levels and maturity models, 3rd Edition. [online] URL: http://www.isaca.org. Accessed 17/11/2007.

IT Governance Institute. 2002. Management guidelines DS2 delivery and support. Managing third-party services, 3rd Edition. [online] URL: http://www.isaca.org. Accessed 17/11/2007.

Kern, T., Willcocks, L. P. \& Lacity, M.C. 2002. 'Application service provision: Risk assessment and mitigation’, MIS Quarterly Executive 1(2):113 - 126.

Kliem, R. 1999, 'Managing the risks of outsourcing agreements', Information System Management, 15(3):91 93.

KPMG. 2000. IT risk management benchmarking V4 questionnaire. Management of information. Information Risk Management. [online] URL: http//www.isaca.org Accessed 10/11/2007.

KPMG. 2003. 'IT risk management benchmarking V2 selfassessment'. [online] URL: http//www.isaca.org Accessed $10 / 11 / 2004$

Lacity, M. 2002. 'Lessons in global information technology sourcing', IEEE, 35(8):26 - 33.

Leenders, M. R. \& Blenkhorn, D. L. 1988. Reverse marketing. The new buyer-supplier relationship. New York: The Free Press, Macmillan.

Lehmann, C. 2003a, 'Assessing supplier risk: Part 1'. MetaGroup Research [online] URL: http://www metagroup.com. Accessed 11/11/2007.

Lehmann, C. 2003b. 'Assessing supplier risk: Part 2'. MetaGroup Research [online] URL: http://www metagroup.com. Accessed 11/11/2007.

Leonard, A.C. 2000. 'A conceptual framework for managing relationship between all participants during IT service and 
support activities', South African Journal of Industrial Engineering, 13(2):81-96.

Hornby, A.S. 1995. Oxford advanced learner's dictionary of current English. Oxford: Oxford University Press.

Mphasis, 2002. 'Management discussion of risks and concerns'. [online] URL:

http://www.mphasis.com/pdfs/MphasiS_Q4_FY03_MD\&A

\%20_of_Risks_Concerns.pdf. Accessed 7/11/2003.

Melymuka, K. 2003. 'How will you manage your suppliers?’, Computer world 37(1): 32-33.

MetaGroup. 2002. 'MetaFACts: IT Spending Quarterly Review and Outlook'. First Albany - Meta Technology Research. [online] URL: http://www metagroup.com. Accessed 20/2/2004.

MetaGroup. 2003. 'Refining information value from supply chains', MetaGroup IT Leadership \& Value Management Newsletter, December 2003. [online] URL: http://www.metagroup.com. (Accessed 20/2/2004).

Murray, S. 1998. 'How much, how good,' The Banker, 149(874): $40-42$.

Naidoo, R. 2002. Corporate governance. Cape Town: Double Storey Books, Juta.

Porter, M.E. 2001. 'Strategy and the Internet,' Harvard Business Review, 79(3): 63-78.

Proszesky-Kuschke, B. 2003. 'Despositum and escrow: Their current application in computer source code in South African law', De Jure: 278 - 288.

Segil, L. 1996. Intelligent business alliances. How to profit using today's most important strategic tool. New York: Random House Inc.

Software Engineering Institute (SEI). 2003. 'Risk management paradigm. Risk management overview. Carnegie Mellon University, Pittsburgh'. [online] URL: http://www.sei.cmu.edu/programs/sepm/risk/risk.mgmt.over view.html. Accessed 12/11/2003.

Steenstrup, K., Kolsky, E., Thompson, E., White, A., Purchase, E. \& Topolinski, T. 2003. 'How to assess an application supplier's financial stability'. Tactical guidelines TG-19-7111, Gartner [online] URL:

http;//www.gartner.com. Accessed 10/11/2007.

Suh, B. \& Han I. 2002. 'The IS risk analysis based on a business model', Information and Management 41(2):149 158.

The Committee of Sponsoring Organisations of the Treadway Commission (COSO). 2003. 'Enterprise risk management framework. Exposure draft for public comment'. [online] URL: http://www.erm.coso.org. Accessed July 2003.

The Institute of Internal Auditors. 1998. List of risk analysis, assessment and management tools, Vol. 1. [online] URL:http://www.theiia.org/itaudit/index.cfm?fuseaction=for um\&fid=207. Accessed 20/2/2004.

Tittle, J. G., Dupont, C. P., Fleming, R. G. \& Hoefer III, A. 2002. 'Measuring value in client-vendor relationships'. [online] URL:

http://www.csc.com/solutions/applicationoutsourcing/knowl edgelibrary/914.shtml. Accessed 12/11/2003.

Varon, E. 2003. 'Getting the best from your vendors (What really works)'. [online] URL:

http://www.cio.com/archive/110103/vendor.html. Accessed 12/11/2003.

Vecchiatto, P. 2003. 'Software vendors disappearing, says Gartner'. [online] URL:

http://196.30.226.221/sections/quickprint/print.asp?SotryID $=134286$. Accessed 12/11/2003.

Ward, J. \& Griffiths, P. 1996. Strategic planning for information systems. $2^{\text {nd }}$ Edition. England: John Wiley \& Sons, reprinted June 1998.

Watkins, M. D. \& Bazerman, M. H. 2003. 'Predictable surprises: The disasters you should have seen coming', Harvard Business Review, March: 72 - 80.

Yin, R. K. 2003. Case study research: Design and methods. 3rd Edition. USA: Sage Publications. 


\section{Appendix A}

\section{ICT Supplier Vulnerabilities identified in literature}

\begin{tabular}{|c|c|c|}
\hline $\begin{array}{l}\text { Vulnerability } \\
\text { Category }\end{array}$ & Vulnerability & Reference \\
\hline \multirow{9}{*}{$\begin{array}{l}\text { Poor service agreements } \\
\text { and management thereof }\end{array}$} & Services Agreements are not properly defined & \multirow{2}{*}{$\begin{array}{l}\text { IT Governance Institute, 2002, Management Guidelines DS2 } \\
\text { Delivery and Support. Managing Third-party Services, 3rd ed., p. } 64 \\
65\end{array}$} \\
\hline & $\begin{array}{l}\text { Technical and organisational interfaces are not } \\
\text { documented }\end{array}$ & \\
\hline & $\begin{array}{l}\text { Measurement is based on technical metrics only - not } \\
\text { business objectives }\end{array}$ & $\begin{array}{l}\text { t Cosgroe, Lorraine, 2003, 'Maximising Value from IT Vendors. } \\
\text { Ware.' } 4 \text { Nov 2003, CIO Research Reports }\end{array}$ \\
\hline & $\begin{array}{l}\text { Low service cost vs service capability - you get what } \\
\text { you pay for }\end{array}$ & $\begin{array}{l}\text { Cosgroe, Lorraine, 2003, 'Maximising Value from IT Vendors. } \\
\text { Ware.' } 4 \text { Nov 2003, CIO Research Reports }\end{array}$ \\
\hline & Service measurement is not agreed & $\begin{array}{l}\text { Fernandez, Ricardo R, 1995, Total Quality in Purchasing and } \\
\text { supplier management. St. Lucie Press }\end{array}$ \\
\hline & No formal SLA/s in place & \\
\hline & $\begin{array}{l}\text { No regular review of Service Agreement against } \\
\text { original objectives }\end{array}$ & $\begin{array}{l}\text { KPMG 2000, 'IT Risk Management Benchmarking V4 } \\
\text { Questionnaire. Management of Information', Information Risk }\end{array}$ \\
\hline & $\begin{array}{l}\text { No completion, review or termination date of Service } \\
\text { Agreement }\end{array}$ & Management, Aug. 2000 \\
\hline & Problem resolution procedures are not documented & Conversation with IBM Consultant \\
\hline \multirow{15}{*}{$\begin{array}{l}\text { Poor contracts and } \\
\text { management thereof }\end{array}$} & No Formal agreements in place before work starts & $\begin{array}{l}\text { IT Governance Institute, 2002, Management Guidelines DS2 } \\
\text { Delivery and Support. Managing Third-party Services, } 3^{\text {rd }} \text { ed., } \\
\text { p. } 64,65\end{array}$ \\
\hline & \multirow{2}{*}{$\begin{array}{l}\text { No formal process to ensure formal agreements \& } \\
\text { legal advice }\end{array}$} & $\begin{array}{l}\text { IT Governance Institute, 2002, Management Guidelines DS2 } \\
\text { Delivery and Support. Managing Third-party Services, } 3^{\text {rd }} \text { ed., } \\
\text { p. } 64,65\end{array}$ \\
\hline & & $\begin{array}{l}\text { Berinato, Scott, } 1 \text { February 2004, 'You Sue, You Lose: The } \\
\text { high cost of Litigation'. ClO.com }\end{array}$ \\
\hline & $\begin{array}{l}\text { Contract does not reflect the work or is not } \\
\text { ppropriately defined }\end{array}$ & $\begin{array}{l}\text { IT Governance Institute, 2002, Management Guidelines DS2 } \\
\text { Delivery and Support. Managing Third-party Services, } 3^{\text {rd }} \text { ed., } \\
\text { p. } 64,65\end{array}$ \\
\hline & \multirow[t]{2}{*}{ Exit, penalties and rewards not contractually agreed } & $\begin{array}{l}\text { IT Governance Institute, } 2002 \text {, Management Guidelines DS2 } \\
\text { Delivery and Support. Managing Third-party Services, } 3^{\text {rd }} \text { ed., } \\
\text { p. } 64,65\end{array}$ \\
\hline & & $\begin{array}{l}\text { Berinato, Scott, } 1 \text { February 2004, 'You Sue, You Lose: The } \\
\text { high cost of Litigation'. CIO.com }\end{array}$ \\
\hline & No Non-disclosure agreement between the parties & \multirow{3}{*}{$\begin{array}{l}\text { IT Governance Institute, 2002, Management Guidelines DS2 } \\
\text { Delivery and Support. Managing Third-party Services, } 3^{\text {rd }} \text { ed., } \\
\text { p. } 64,65\end{array}$} \\
\hline & $\begin{array}{l}\text { Not utilising Escrow contracts in legal uncertainties } \\
\text { (Depostitum and escrow: their current application in } \\
\text { computer source code in South African Law) }\end{array}$ & \\
\hline & $\begin{array}{l}\text { Intellectual property rights and liabilities are not } \\
\text { agreed between the parties }\end{array}$ & \\
\hline & $\begin{array}{l}\text { Unclear or vague Issue resolution, Mediation and } \\
\text { Arbitration procedures in contract }\end{array}$ & \multirow{2}{*}{$\begin{array}{l}\text { Berinato, Scott, } 1 \text { February 2004, 'You Sue, You Lose: The } \\
\text { high cost of Litigation'. ClO.com }\end{array}$} \\
\hline & $\begin{array}{l}\text { The easily foreseeable problems e.g. project failure } \\
\text { are not dealt with in formal agreements }\end{array}$ & \\
\hline & Supplier has invariable pricing model & \multirow{2}{*}{$\begin{array}{l}\text { Cosgroe, Lorraine, 2003, 'Maximising Value from IT Vendors. } \\
\text { Ware.' } 4 \text { Nov 2003, CIO Research Reports }\end{array}$} \\
\hline & Contract period is too long or too short & \\
\hline & $\begin{array}{l}\text { Not all elements of scope of work contractually } \\
\text { agreed between the parties }\end{array}$ & $\begin{array}{l}\text { KPMG 2000, 'IT Risk Management Benchmarking V4 } \\
\text { Questionnaire. Management of Information', Information Risk } \\
\text { Management, Aug. } 2000\end{array}$ \\
\hline & Not updating contracts periodically & $\begin{array}{l}\text { Lehmann, Carl, } 24 \text { Oct. 2003, 'Assessing Supplier Risk: Part 2', } \\
\text { MetaGroup Research Delta } 2575\end{array}$ \\
\hline
\end{tabular}




\begin{tabular}{|c|c|c|}
\hline & Non-compete clauses omitted from contracts & $\begin{array}{l}\text { Kern, Thomas, Willcocks, Leslie P. and Lacity, Mary C., 2002, } \\
\text { 'Application Service Provision: Risk assessment and mitigation', } \\
\text { MIS Quarterly Executive Vol. 1, No. 2., J une 2002, University } \\
\text { of Minnesota }\end{array}$ \\
\hline & Omitting sub-contractor management in contract & $\begin{array}{l}\text { Kliem, Ralph, 1999, 'Managing the risks of outsourcing } \\
\text { agreements', Information System Management, Summer } 1999\end{array}$ \\
\hline \multirow{2}{*}{$\begin{array}{l}\text { Inappropriate and poor } \\
\text { service delivery monitoring }\end{array}$} & $\begin{array}{l}\text { Process for monitoring economic value, service } \\
\text { delivery and relationship quality }\end{array}$ & $\begin{array}{l}\text { IT Governance Institute, 2002, Management Guidelines DS2 } \\
\text { Delivery and Support. Managing Third-party Services, } 3^{\text {rd }} \text { ed., } \\
\text { p. } 64,65\end{array}$ \\
\hline & $\begin{array}{l}\text { No Supplier management system for continuous } \\
\text { performance rating, also against purchase order \& } \\
\text { contract compliance }\end{array}$ & $\begin{array}{l}\text { Lehmann, Carl, } 24 \text { Oct. 2003, 'Assessing Supplier Risk: Part 2', } \\
\text { MetaGroup Research Delta } 2575\end{array}$ \\
\hline \multirow{3}{*}{$\begin{array}{l}\text { Inappropriate and poor } \\
\text { Service delivery reporting }\end{array}$} & Irregular service delivery reporting & $\begin{array}{l}\text { Kliem, Ralph, 1999, 'Managing the risks of outsourcing } \\
\text { agreements', Information System Management, Summer } 1999\end{array}$ \\
\hline & $\begin{array}{l}\text { Poor performance not linked to contractual rewards \& } \\
\text { penalties }\end{array}$ & $\begin{array}{l}\text { Kliem, Ralph, 1999, 'Managing the risks of outsourcing } \\
\text { agreements', Information System Management, Summer } 1999\end{array}$ \\
\hline & $\begin{array}{l}\text { No formal process to report economic value, service } \\
\text { delivery and relationship quality }\end{array}$ & $\begin{array}{l}\text { IT Governance Institute, 2002, Management Guidelines DS2 } \\
\text { Delivery and Support. Managing Third-party Services, 3rd ed., } \\
\text { p. } 64,65\end{array}$ \\
\hline \multirow{2}{*}{$\begin{array}{l}\text { High level of dependency } \\
\text { on technology }\end{array}$} & High degree of product customisation & $\begin{array}{l}\text { Cosgroe, Lorraine, 2003, 'Maximising Value from IT Vendors. } \\
\text { Ware.' } 4 \text { Nov 2003, ClO Research Reports }\end{array}$ \\
\hline & $\begin{array}{l}\text { High level of integrated management between } \\
\text { supplier and ITO }\end{array}$ & $\begin{array}{l}\text { Software Engineering Institute (SEI) 2003, 'Risk Management } \\
\text { Paradigm. Risk Management Overview', Carnegie Mellon } \\
\text { University, Pittsburgh }\end{array}$ \\
\hline \multirow{4}{*}{$\begin{array}{l}\text { Poor supplier } \\
\text { management practices }\end{array}$} & Supplier relationship is build only on personal levels & \multirow{3}{*}{$\begin{array}{l}\text { Watkins, Michael D. and Bazerman, Max H., 2003, 'Predictable } \\
\text { Surprises: The Disasters you should have seen coming', } \\
\text { Harvard Business Review, March } 2003 \text { ( } 72-80) \text {. }\end{array}$} \\
\hline & Subjective views on suppliers & \\
\hline & Too much influence from special interests & \\
\hline & Poor assessment of own IT portfolio & $\begin{array}{l}\text { Lacity, Mary, 2002, 'Lessons in Global Information Technology } \\
\text { Sourcing', University of Missouri, St.Louis, IEEE, Aug. } 2002 \text { ( } 26 \\
\text { - 33) }\end{array}$ \\
\hline \multirow[b]{2}{*}{$\begin{array}{l}\text { Implementing New or } \\
\text { Complex Technology }\end{array}$} & Supplier manipulates uncertainties & \multirow{2}{*}{$\begin{array}{l}\text { Ford, David, et al., 1998, Managing Business Relationships, } \\
\text { J ohn Wily \& Sons, Ltd., England, p18 - } 25\end{array}$} \\
\hline & $\begin{array}{l}\text { Not implement and Use technology according to its } \\
\text { purpose }\end{array}$ & \\
\hline \multirow{2}{*}{$\begin{array}{l}\text { Poor quality control in } \\
\text { implementing and } \\
\text { managing technology }\end{array}$} & $\begin{array}{l}\text { Not exchange appropriate information to improve } \\
\text { quality control }\end{array}$ & $\begin{array}{l}\text { Fernandez, Ricardo R, 1995, Total Quality in Purchasing and } \\
\text { supplier management. St. Lucie Press }\end{array}$ \\
\hline & Flawed risk management process & $\begin{array}{l}\text { Lehmann, Carl, } 24 \text { Oct. 2003, 'Assessing Supplier Risk: Part 1', } \\
\text { MetaGroup Research Delta } 2574\end{array}$ \\
\hline \multirow{9}{*}{$\begin{array}{l}\text { Not nurturing the quality of } \\
\text { the Relationship }\end{array}$} & Not analysing cost and service level variances & \multirow{3}{*}{$\begin{array}{l}\text { IT Governance Institute, 2002, Management Guidelines DS2 } \\
\text { Delivery and Support. Managing Third-party Services, } 3^{\text {rd }} \text { ed., } \\
\text { p. } 64,65\end{array}$} \\
\hline & $\begin{array}{l}\text { No relationship owner assigned to ensure quality of } \\
\text { relationship }\end{array}$ & \\
\hline & No supplier performance rewards and penalties & \\
\hline & Inability to manage supplier relationships & $\begin{array}{l}\text { Kern, Thomas, Willcocks, Leslie P. and Lacity, Mary C., 2002, } \\
\text { 'Application Service Provision: Risk assessment and mitigation', } \\
\text { MIS Quarterly Executive Vol. 1, No. 2., J une 2002, University } \\
\text { of Minnesota }\end{array}$ \\
\hline & $\begin{array}{l}\text { Assess \& Understand what has happened in the } \\
\text { relationship previously when contracting new work }\end{array}$ & \multirow{3}{*}{$\begin{array}{l}\text { Ford, David, et al., 1998, Managing Business Relationships, } \\
\text { ohn Wily \& Sons, Ltd., England, p6-7 }\end{array}$} \\
\hline & $\begin{array}{l}\text { Not understanding the positioning of the relationship } \\
\text { in the relationship life-cycle (pre-relationship, } \\
\text { Exploratory, Developing, Stable stage) }\end{array}$ & \\
\hline & $\begin{array}{l}\text { Not adjusting management level when change in } \\
\text { relationship status }\end{array}$ & \\
\hline & Contrained communications between parties & \multirow{2}{*}{$\begin{array}{l}\text { Software Engineering Institute (SEI) 2003, 'Risk Management } \\
\text { Paradigm. Risk Management Overview', Carnegie Mellon } \\
\text { University, Pittsburgh }\end{array}$} \\
\hline & $\begin{array}{l}\text { No team work between the parties when delivery to } \\
\text { the business }\end{array}$ & \\
\hline
\end{tabular}


Relationship yields low economic value
Flawed outsourcing partnership/s

No formal process for due diligence before partner selection

Unclear relationship purpose and economic value thereof

Thorough understanding of quality, quantity, price
and service of purchase
and service of purchase

Rigid product offerings - all or nothing Quality of free consulting

References and capacity to deliver not validated

Supplier's expectations needs to be managed/realistic

Not understanding supplier's previous Project delivery failures

Not recognising costs other than "price" of pard, et al, 1998, Managing Business Relationships, Not recognising costs other than "price" of purchasing J ohn Wily \& Sons, Ltd., England, p116 (production, goods handling, storage, capital, relationship handling, admin \& dev costs)

No or ad hoc process of relationship value assessment

\begin{tabular}{|l|}
\hline Undefined processing levels \\
\hline Poor security audit results \\
\hline
\end{tabular}

Not addressing monitoring and contingency requirements

IT Governance Institute, 2002, Management Guidelines DS2 Delivery and Support. Managing Third-party Services, $3^{\text {rd }}$ ed., p. 64,65

Contract not cover conclusion/exit and handover No tendering process followed

No management framework

No board level accountability defined

Low level of control in outsourcing management

Re-negotiating contracts based on previous contract instead on market prices

Excess fees for services assumed were under the baseline umbrella agreement

Not understanding the market options when selecting the best supplier

Not understanding the various Outsourcing types/options

Inflexible to changing business needs

Continious service level failure

Joint venture is not attracting/keeping external customers

Not managing the user-supplier interface

Outsourcing noncore activities that might be future competitive advantage

Loose or standard agreements

No change mechanisms in contracts (realignment points, fluctuating volume of demand, etc)

Contracts term too long term

Not keep critical core competencies in-house (IT Governance; Business requirements; ensuring tech ability and architecture \& managing external suppliers)

Assesing Application Service provision outsourcing with unique assessment criteria

Lack of maturity and experience to manage outsourcing
KPMG 2000, 'IT Risk Management Benchmarking V4 Questionnaire. Management of Information', Information Risk Management, Aug. 2000

t

$\sqrt{2}$

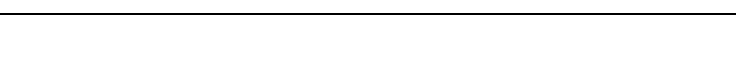

IT Governance Institute, 2002, Management Guidelines DS2

Delivery and Support. Managing Third-party Services, $3^{\text {rd }}$ ed., p. 64,65

Leenders, Michiel R., and Blenkhorn, David L., 1988, Reverse

Marketing. The new Buyer-Supplier Relationship, The Free

Press, Macmillan, New York, USA

Cosgroe, Lorraine, 2003, 'Maximising Value from IT Vendors. Ware.' 4 Nov 2003, ClO Research Reports

Berinato, Scott, 1 February 2004, 'You Sue, You Lose: The high cost of Litigation'. ClO.com 


\begin{tabular}{|c|c|c|}
\hline & Poor transition planning \& management & \\
\hline & $\begin{array}{l}\text { Suppliers lack of maturity and experience in } \\
\text { Outsourcing }\end{array}$ & \\
\hline \multirow{2}{*}{$\begin{array}{l}\text { Poor communication } \\
\text { between the parties }\end{array}$} & Barriers in organisation that impede communications & \multirow{2}{*}{$\begin{array}{l}\text { Watkins, Michael D. and Bazerman, Max H., 2003, 'Predictable } \\
\text { Surprises: The Disasters you should have seen coming', } \\
\text { Harvard Business Review, March } 2003(72-80) \text {. }\end{array}$} \\
\hline & $\begin{array}{l}\text { Organisational silos that disperse information and } \\
\text { responsibility }\end{array}$ & \\
\hline \multirow{16}{*}{$\begin{array}{l}\text { Awareness of supplier's } \\
\text { financial stability/health }\end{array}$} & $\begin{array}{l}\text { Supplier has inappropriate/unstable Sources of } \\
\text { funding }\end{array}$ & \multirow{4}{*}{$\begin{array}{l}\text { Lehmann, Carl, } 24 \text { Oct. 2003, 'Assessing Supplier Risk: Part 1', } \\
\text { MetaGroup Research Delta } 2574\end{array}$} \\
\hline & Supplier has insufficient capital available & \\
\hline & Supplier's Capital "burn rate" too high & \\
\hline & Supplier's projected breakeven points are very high & \\
\hline & Supplier's unviable pricing models & $\begin{array}{l}\text { Cosgroe, Lorraine, 2003, 'Maximising Value from IT Vendors. } \\
\text { Ware.' } 4 \text { Nov 2003, ClO Research Reports }\end{array}$ \\
\hline & Suppliers has poor track record with other customers & \multirow{8}{*}{$\begin{array}{l}\text { Steenstrup, K., Kolsky, E., Thompson, E., White, A., Purchase, } \\
\text { E. and Topolinski, T., } 4 \text { June 2003, 'How to Assess an } \\
\text { Application Supplier's Financial Stability', Tactical Guidelines } \\
\text { TG-19-7111, Gartner }\end{array}$} \\
\hline & Supplier has a negative Income Statement & \\
\hline & $\begin{array}{l}\text { Supplier's Financial results compare poorly with } \\
\text { competitors in industry }\end{array}$ & \\
\hline & Supplier share price is volatile & \\
\hline & Supplier has low number of new deals (per quarter) & \\
\hline & Spplier's 2 largest shareholders has low profit & \\
\hline & Supplier's Revenue per employee is inappropriate & \\
\hline & $\begin{array}{l}\text { Supplier's service offerings onsist of too many low } \\
\text { margin services }\end{array}$ & \\
\hline & $\begin{array}{l}\text { Supplier is exposed to many Foreign exchange } \\
\text { transactions /accounting }\end{array}$ & \multirow{3}{*}{ Mphasis, 2002,'Management discussion of risks and concerns' } \\
\hline & Supplier Liquidity is low & \\
\hline & $\begin{array}{l}\text { Supplier is using expensive funding for large capital } \\
\text { expenditure }\end{array}$ & \\
\hline \multirow{13}{*}{$\begin{array}{l}\text { Insight into supplier's } \\
\text { future survivability }\end{array}$} & Supplier does not have a clear Product vision & \multirow{2}{*}{$\begin{array}{l}\text { Steenstrup, K., Kolsky, E., Thompson, E., White, A., Purchase, } \\
\text { E. and Topolinski, T., } 4 \text { J une 2003, 'How to Assess an } \\
\text { Application Supplier's Financial Stability', Tactical Guidelines } \\
\text { TG-19-7111, Gartner }\end{array}$} \\
\hline & Supplier has poor investment decision making ability & \\
\hline & Predicted life expectancy of supplier is short & $\begin{array}{l}\text { Kliem, Ralph, 1999, 'Managing the risks of outsourcing } \\
\text { agreements', Information System Management, Summer } 1999\end{array}$ \\
\hline & $\begin{array}{l}\text { Supplier is dependent on large \% of income from few } \\
\text { large customers }\end{array}$ & \multirow{10}{*}{ Mphasis, 2002,'Management discussion of risks and concerns' } \\
\hline & Supplier only play in one vertical market & \\
\hline & Supplier support is geographical concentrated & \\
\hline & Supplier has poor international operations & \\
\hline & $\begin{array}{l}\text { Supplier has outstanding delivery disputes with } \\
\text { customers }\end{array}$ & \\
\hline & Supplier has too many fixed price contracts & \\
\hline & Supplier is offering massive discounting & \\
\hline & Supplier has high Merger \& Acquisition activity & \\
\hline & $\begin{array}{l}\text { Supplier is unable to attract and retain professional } \\
\text { talent }\end{array}$ & \\
\hline & Supplier only offer low margin products & \\
\hline \multirow{2}{*}{$\begin{array}{l}\text { Supplier's inappropriate } \\
\text { solution/product or service } \\
\text { offering }\end{array}$} & $\begin{array}{l}\text { Niche technology/solution with no alternative } \\
\text { suppliers }\end{array}$ & $\begin{array}{l}\text { Cosgroe, Lorraine, 2003, 'Maximising Value from IT Vendors. } \\
\text { Ware.' } 4 \text { Nov 2003, CIO Research Reports }\end{array}$ \\
\hline & Poor software quality that requires many patches & $\begin{array}{l}\text { Desmond, Paul, 2003, A better way to deal with vulnerabilities. } \\
\text { Earthweb. } 10 \text { July } 2003 \text {. J upitermedia Corporation }\end{array}$ \\
\hline
\end{tabular}




\begin{tabular}{|c|c|c|}
\hline \multirow{12}{*}{$\begin{array}{l}\text { Undisclosed information of } \\
\text { suppliers internal } \\
\text { operations }\end{array}$} & $\begin{array}{l}\text { Inability to work with other suppliers during project } \\
\text { implementation }\end{array}$ & $\begin{array}{l}\text { Cosgroe, Lorraine, 2003, 'Maximising Value from IT Vendors. } \\
\text { Ware.' } 4 \text { Nov 2003, CIO Research Reports }\end{array}$ \\
\hline & $\begin{array}{l}\text { Supplier is overselling its capabilities for software } \\
\text { development }\end{array}$ & \multirow{2}{*}{$\begin{array}{l}\text { Kern, Thomas, Willcocks, Leslie P. and Lacity, Mary C., 2002, } \\
\text { 'Application Service Provision: Risk assessment and mitigation' } \\
\text { MIS Quarterly Executive Vol. 1, No. 2., J une 2002, University } \\
\text { of Minnesota }\end{array}$} \\
\hline & Poorly selected Sub-contractors $/ 3^{\text {rd }}$ party & \\
\hline & Supplier has insufficient Security Policy & $\begin{array}{l}\text { Goodwin, Bill, } 7 \text { Nov. 2003, } 11 \text { 'September attacks key driver } \\
\text { for IT security investment, survey finds', ComputerWeekly.com }\end{array}$ \\
\hline & Unstable Executive Management & $\begin{array}{l}\text { Lehmann, Carl, } 24 \text { Oct. 2003, 'Assessing Supplier Risk: Part 1', } \\
\text { MetaGroup Research Delta } 2574\end{array}$ \\
\hline & $\begin{array}{l}\text { Supplier's policies and procedures are not clearly } \\
\text { counicated }\end{array}$ & \multirow{5}{*}{$\begin{array}{l}\text { Institute of Directors, 2002, 'King Report on Corporate } \\
\text { Governance of South Africa 2002', Centre of Directorship and } \\
\text { Corporate Governance }\end{array}$} \\
\hline & Operating environment - customer base \& potential & \\
\hline & Supplier has high $\%$ of new personnel & \\
\hline & New or revamped technology & \\
\hline & $\begin{array}{l}\text { Supplier has volatile products acquisitions and } \\
\text { disposals including distributorship }\end{array}$ & \\
\hline & Bureaucracy affect performance and response times & $\begin{array}{l}\text { Segil, Larraine, 1996, Intelligent Business Alliances. How to } \\
\text { Profit Using Today's Most Important Strategic Tool, Times } \\
\text { Business. Random House. New York }\end{array}$ \\
\hline & Supplier's disaster recovery is insufficient & Mphasis, 2002,'Management discussion of risks and concerns' \\
\hline \multirow{8}{*}{$\begin{array}{l}\text { Supplier's lack of } \\
\text { Enterprise risk } \\
\text { assessment }\end{array}$} & Not understanding business impact of delivery failure & $\begin{array}{l}\text { IT Governance Institute, } 2002 \text {, Management Guidelines DS2 } \\
\text { Delivery and Support. Managing Third-party Services, } 3^{\text {rd }} \text { ed., } \\
\text { p. } 64,65\end{array}$ \\
\hline & Parties do not have a shared product vision & \multirow{2}{*}{$\begin{array}{l}\text { Software Engineering Institute (SEI) 2003, 'Risk Management } \\
\text { Paradigm. Risk Management Overview', Carnegie Mellon } \\
\text { University, Pittsburgh }\end{array}$} \\
\hline & $\begin{array}{l}\text { Supplier does not have a forward looking view on its } \\
\text { service/product offerings }\end{array}$ & \\
\hline & $\begin{array}{l}\text { Not clearly understand role of suppliers in the IT } \\
\text { value chain }\end{array}$ & $\begin{array}{l}\text { MetaGroup, 2003, 'Refining Information Value from Supply } \\
\text { Chains', MetaGroup IT Leadership \& Value Management } \\
\text { Newsletter, Dec. } 2003\end{array}$ \\
\hline & $\begin{array}{l}\text { Not continuously monitoring supplier exposure over } \\
\text { time }\end{array}$ & $\begin{array}{l}\text { Lehmann, Carl, } 24 \text { Oct. 2003, 'Assessing Supplier Risk: Part 2', } \\
\text { MetaGroup Research Delta } 2575\end{array}$ \\
\hline & $\begin{array}{l}\text { Failure to update business continuity plans to adjust } \\
\text { from supplier's service delivery failures }\end{array}$ & $\begin{array}{l}\text { Lehmann, Carl, } 24 \text { Oct. 2003, 'Assessing Supplier Risk: Part 1', } \\
\text { MetaGroup Research Delta } 2574\end{array}$ \\
\hline & Not using suppliers that provide New or fresh insights & $\begin{array}{l}\text { Cosgroe, Lorraine, 2003, 'Maximising Value from IT Vendors. } \\
\text { Ware.' } 4 \text { Nov 2003, ClO Research Reports }\end{array}$ \\
\hline & $\begin{array}{l}\text { Fixed pricing models based only on technical } \\
\text { implementation and not value delivery or business } \\
\text { gainshare }\end{array}$ & $\begin{array}{l}\text { Cosgroe, Lorraine, 2003, 'Maximising Value from IT Vendors. } \\
\text { Ware.' } 4 \text { Nov 2003, CIO Research Reports }\end{array}$ \\
\hline \multirow{2}{*}{$\begin{array}{l}\text { Supplier's non-compliance } \\
\text { to Legal and Regulatory } \\
\text { requirements }\end{array}$} & \multirow{2}{*}{$\begin{array}{l}\text { Poor Corporate Governance and business risk } \\
\text { management }\end{array}$} & $\begin{array}{l}\text { IT Governance Institute, 2002, Management Guidelines DS2 } \\
\text { Delivery and Support. Managing Third-party Services, } 3^{\text {rd }} \text { ed., } \\
\text { p. } 64,65\end{array}$ \\
\hline & & $\begin{array}{l}\text { Institute of Directors, 2002, 'King Report on Corporate } \\
\text { Governance of South Africa 2002', Centre of Directorship and } \\
\text { Corporate Governance }\end{array}$ \\
\hline $\begin{array}{l}\text { Supplier breach } \\
\text { confidentiality }\end{array}$ & $\begin{array}{l}\text { Insider trading due to access to confidential partner } \\
\text { information }\end{array}$ & $\begin{array}{l}\text { Naidoo, Ramani, 2002, Corporate Governance. Double Storey } \\
\text { Books, Juta, Cape Town, South Africa }\end{array}$ \\
\hline $\begin{array}{l}\text { Supplier's lack of service } \\
\text { Availability \& Reliability }\end{array}$ & $\begin{array}{l}\text { Poor Systems \& Internet availability from ASP } \\
\text { supplier }\end{array}$ & $\begin{array}{l}\text { Kern, Thomas, Willcocks, Leslie P. and Lacity, Mary C., 2002, } \\
\text { 'Application Service Provision: Risk assessment and mitigation', } \\
\text { MIS Quarterly Executive Vol. 1, No. 2., June 2002, University } \\
\text { of Minnesota }\end{array}$ \\
\hline \multirow{2}{*}{$\begin{array}{l}\text { Supplier's poor } \\
\text { responsiveness to risk }\end{array}$} & Under or over pricing & $\begin{array}{l}\text { Varon, Elana, 2003, Getting the best from your vendors (What } \\
\text { really works). CIO, } 1 \text { Nov } 2003\end{array}$ \\
\hline & Supplier's resource availability & Conversation with IBM Consultant \\
\hline \multirow{2}{*}{$\begin{array}{l}\text { Supplier's external } \\
\text { organisational }\end{array}$} & Supplier Merger and Acquisition activity & \multirow{2}{*}{$\begin{array}{l}\text { Lehmann, Carl, } 24 \text { Oct. 2003, 'Assessing Supplier Risk: Part 1', } \\
\text { MetaGroup Research Delta } 2574\end{array}$} \\
\hline & Exposure to the effects of Lawsuits against supplier & \\
\hline
\end{tabular}


accountability

Supplier's status regarding Regulatory bodies it reports or needs to comply to

Supplier is not managing its supplier Partnerships or Strategic Alliances

Supplier is not complying to Regulatory requirements Mphasis, 2002,'Management discussion of risks and concerns' 
Appendix B - Case Study ICT Supplier Key Relationship Vulnerabilities

(Due to confidentiality of information, reference details only available on special request)

Poor service agreements and management thereof
Poor contracts and management thereof
Inappropriate and poor service delivery monitoring

\begin{tabular}{|c|c|}
\hline Vulnerability & Reference \\
\hline Only short term view of SLA performance and not trend & \multirow{3}{*}{ Dashboards } \\
\hline Ineffective SLA level problem solving & \\
\hline No specific focus on mission critical SLA's & \\
\hline Reliability of service not improving & \multirow{2}{*}{ T2 } \\
\hline Volatile/non-stable service delivery & \\
\hline Inability to do analysis of performance & D10 \\
\hline Weakness in the SLA's & T15 \\
\hline No Penalties in SLA's & G5 \\
\hline Persons that set-up SLA also measure it & \multirow{2}{*}{ Int. 6} \\
\hline Inappropriate SLA measures & \\
\hline No SLA's when handed over to production & D20 \\
\hline SLA's not derived from contract & Int. 5 \\
\hline All SLA's are at technical levels & G5 \\
\hline Processes and procedures lacking & $\mathrm{T} 10$ \\
\hline Unmanaged Strategic Alliance expectations & \multirow{6}{*}{$\begin{array}{l}\text { Strategic Alliance } \\
\text { MOU's }\end{array}$} \\
\hline Weak or inappropriate Initiatives/project agreements & \\
\hline Poor Initiatives/Project delivery agreement & \\
\hline No Confidentiality agreement relating to 3rd party use of information & \\
\hline Not explicit on which country's Governing laws is the contracting basis & \\
\hline No Confidential Information usage clause/agreement & \\
\hline No view of Initiatives/Project performance & \multirow{2}{*}{ Dashboards } \\
\hline Re-active contract renewal & \\
\hline Contract content agreed, but not actually signed & T9 \\
\hline No consideration for exit clauses or terminations & \multirow{2}{*}{ T12 } \\
\hline Non-performance is not considered and formalised & \\
\hline Too many contracts - ineffective management & T14 \\
\hline Unmanaged "usage" contract that effects budget & T17 \\
\hline No Master agreement to cover essential static basics & G5 \\
\hline Contracts with flexible currency & \multirow{3}{*}{ Int. 5} \\
\hline Re-active/late contract assessment when up for renewal & \\
\hline Not managing contract lifecycles & \\
\hline Inappropriate licensing agreement & M3 \\
\hline Contract and details not communicated to Project Manager & Int. 4 \\
\hline Inappropriate contract that does not reflect actual costs & \multirow{3}{*}{ Int. 6} \\
\hline No penalties or rewards in contracts & \\
\hline Rigid contracts that cannot be adjusted to reflect what we want/use & \\
\hline Not have a contract portfolio view & Int.3 \\
\hline Contract period too long & Int. 2 \\
\hline Contract agreed, but not signed & 116 \\
\hline Not reviewing projects and assignments & $\begin{array}{l}\text { Strategic Alliance } \\
\text { MOU's }\end{array}$ \\
\hline Project/Initiative status overview & \multirow{2}{*}{ Dashboards } \\
\hline Inconsistent strategic/overall monitoring & \\
\hline Non SLA services MTTR high & \multirow[t]{2}{*}{$\mathrm{T} 2$} \\
\hline Non SLA services high failures & \\
\hline $3^{\text {rd }}$ Party services influence are unclear & T10 \\
\hline Not all projects is based on direct financial benefits & T14 \\
\hline Poor project controls & G5 \\
\hline ineffective contract management & Int. 5 \\
\hline Deficient technology update reports & D20 \\
\hline
\end{tabular}


Inappropriate and poor Service delivery reporting

High level of dependency on technology

Poor supplier management practices

Implementing New or Complex Technology

Poor quality control in implementing and managing technology

Not nurturing the quality of the Relationship
Focus on activities/initiatives/projects in isolation and not across the enterprise

Dashboards

Supplier technology has a high level of embedded ness in the technology architecture

No internal awareness of the supplier relationship

Niche solutions provider

Informal communications

High level of interdependency of technologies

High level of Authentication and Authorisation of supplier into your systems

Reciprocity

Interdependency of supplier's technologies with other technologies

Joint marketing disagreements

Not empowering customer staff to understand technical problems

Supplier is not reporting of all sales \& marketing efforts across enterprise

Not reporting of all formal engagements

Supplier relationship is build only on personal levels

Not keeping abreast of global economic \& ICT supplier trends

Ad hoc or once of due diligence of supplier

Country risks

Disconnect between SBU/GSF requirements/projects

Leading edge technology

Disregard/ignorance of Architectural direction \& standards

Poor co-ordination between systems interfaces

Too much hands off on project

Experimental ventures might not have value

Poor project management and/or planning

Multiple software from different vendors in technology domain

Weak risk management on security issues

Project too large and unmanageable

No external evaluation of critical work

No audits on deliverables

No Post -implementation reviews

No communications process of confidential info to lower levels

Dependency on monopoly supplier

No Good will between parties

Deteriorating Co-operation keenness

Sharing of information

Poor or no Relationship Governance

Poor or no Relationship trust

Relationship conflict

Sharing of Strategic information

Scrambled Communications

No relationships owner for accountable relationship quality

Supplier has no opportunity to solicit further business

Interaction inefficiency

Diminishing interest of Senior involvement in relationship over time

Poor accounting (invoice \& payment) practices between the parties

Too few formal discussion

Relationship interaction with Business at an inappropriate level

Poor reputation for partnering
T3

$\mathrm{T} 1$

$\mathrm{T7}$

T10

Absa Strategic

Alliance

measurement. 3

Nov 2003

Absa Group IT

Road show

Int. 3 Int. 1

I20,D2

T5

$\mathrm{T} 13$

D17

Int. 4

Int.1

Int.6

Int. 2

I16

$\mathrm{T} 1$

116

I17

Strategic Alliance

MOU's

T2, Int. 6

I17

T12

$\mathrm{T} 13$

117

D19

D20

T9

T1

MOU's

Dashboards

T4

T8

T10

G5

116

Int. 6 
Relationship yields low economic value
Not managing relationship benefit expectations

Not having a shared view of relationship risks

Not exploit existing technology

Not sharing required strategic information

Large ICT expenditure with monopoly supplier

Strategic direction of relationship becomes misaligned

Not tracking the benefits of the relationship

Not achieving stated benefits from relationship

Unknown, untapped opportunities from supplier

Long lead times of initiatives/projects

Pipeline of supplier proposals few

Many small projects with high management costs

Small benefits from costly efforts

Inability to stop projects when necessary

Not levering opportunities from companies in Holdings group

Not levering opportunities from suppliers relationship network

Supplier do $1^{\text {st }}$ to market initiatives with competitors

Supplier not advising on technology trends of the area they play in

Business case not developed for project

Project in Progress without Cost Agreement

Relationship purpose is unclear

Business benefits of projects not clear

Only reporting Financial benefits of the relationship and ignoring the non-financial benefits

Supplier has inadequate DRP policy and procedures

No thorough supplier due diligence before enter into Outsourcing agreement

Supplier has low maturity to manage outsourcing

ITO has low maturity to manage outsourcing

Outsourcing for wrong reasons

Outsourcing core capability

Supplier has inadequate security policies and procedures

Organisational silos disperse information and responsibility the parties

Awareness supplier's financial stability/health

Insight into supplier's future survivability

Undisclosed information of Supplier's Internal Operations

\begin{tabular}{|c|c|}
\hline Supplier Poor financial results & $\mathrm{D} 2$ \\
\hline Supplier Poor product development and weak R \& D & D7 \\
\hline Supplier is a private company not obligated disclose financials & Int. 5 \\
\hline High level of M \& A & Int. 2 \\
\hline Financial instability of supplier's subsidiaries/business in other countries/regions & D13 \\
\hline Not obtaining expert analysis or advice if supplier survivability is sound & Int. 2 \\
\hline Supplier Continuous poor financial results & $\mathrm{D} 2$ \\
\hline Supplier is unaware or not using the appropriate processes $\&$ procedures & \multirow{4}{*}{$\mathrm{T} 12$} \\
\hline Supplier has weak ops problem escalation processes/procedures & \\
\hline Supplier's Business Model with 3rd Party is flawed & \\
\hline $\begin{array}{l}\text { Supplier has to develop it own new policies or policy changes during project } \\
\text { implementation }\end{array}$ & \\
\hline Supplier's operational control lies outside country borders & T13 \\
\hline Supplier's Financial Accounting practices and reporting differ substantially & T14 \\
\hline Supplier has insufficient skills training and resource planning & D4 \\
\hline Supplier's Service delivery operating model and org structure is flawed & 120 \\
\hline
\end{tabular}
Int. 3

Absa Strategic Alliance measurement. 3 Nov 2003

Int. 5 T1

Strategic Alliance MOU's

G1

Dashboards

T2

T2, G5

T3

T5

T14

Int. 4

T17

D13

12

C1

Int. 6

D16

T14

G5

Int. 6

Int. 5

D12 
Supplier's inappropriate solution/product or service offering
Supplier's lack of Enterprise risk assessment
Supplier's non-compliance to Legal and Regulatory requirements
Supplier's poor Corporate Governance and Accounting practices

Suppliers undisclosed Merger \& Acquisitions activity

Supplier keeps insufficient stock levels

Poor time to market - Project implementation - history

Supplier has unreliable Procurement process

ITO has little power to influence solution/product offering for needs

Supplier technology or implementation practice is causing new security issues

Product functionality not leveraged

Supplier gives poor advice and have low knowledge of needs

Supplier Marketing/Selling inappropriate Technology

Service failures have a high impact on the Enterprise

Indirect impact projects have on the larger enterprise

Relationship does not deliver promised value

Large financial exposure to the Supplier

Poor implementation planning of Initiatives/Projects

Business Continuity is not part of project/service delivery

Only ICT participation in Strategic Supplier Meetings

Supplier does not recognise or understand Business priorities

Supplier used as Strategic Advisor

Business consequences of technology

Slipping on Critical timelines of projects

Not measuring business impact of project/service delivery

Suppliers implementation approach is inappropriate

Supplier develops the business case to solicit funding of project or solution

Insufficient knowledge transfer for assessing business impact on projects/technology implementation

Not having a shared view of business risks

Not categorising suppliers to manage relationships appropriately according to business impact

Not calculating business cost of project slippage

Acting in manner that might legally be construed as being one entity

Breaching competition laws

Intellectual Property rights ownership not agreed

$3^{\text {rd }}$ party non-compliance to legal requirements

No policy and regulatory risk assessment

Contract in exit clause if marginal non-compliance

BEE fronting

Supplier breach confidentiality

Supplier's lack of service Availability \& Reliability

Supplier shares Enterprise Confidential Information inappropriately

SLA not linked to seasonal ebbs and flow

Not contractually agreed during pilot or while developing per phase

Not having priority customer status with the suppliers

Supplier is not escalating issues, risks to appropriate levels

Supplier's poor responsiveness to risk

Supplier not available during peak service requirements e.g. for additional capacity

Not making virus patches available fast enough

Supplier does not apply or share best practise

Supplier BEE non-compliance

Supplier's external organisational accountability

Supplier's product flaws
Supplier is not taking part in industry forums

Supplier uses $3^{\text {rd }}$ parties inappropriately

Extensive customisation of technology products
Int. 6

110

Absa PFS

17

T1

D5

D20

Int. 4

Dashboards

T2

Strategic Alliance MOU's

Dashboards

T9

$\mathrm{T} 11$

G5

I17

121

Absa PFS

C4

Int. 5

Int. 3

G6

D18

Strategic Alliance MOU's

Int. 6

T12

Int. 4

G5

Strategic Alliance MOU's

Int. 4

Int. 6

T1

Strategic Alliance MOU's

115

Absa Group IT Road show

119

T5

T5

I15

G5

119 


\begin{tabular}{|c|c|c|}
\hline & Supplier avoids Open Standards & I21, Int. 2 \\
\hline & Hardware/component failure & Absa Group IT \\
\hline & Bug/s in software & Roadshow \\
\hline & Continuous re-active patching & 123 \\
\hline \multirow{6}{*}{$\begin{array}{l}\text { Large financial exposure to } \\
\text { supplier }\end{array}$} & Financial exposure trend - long term or short term misaligned with strategic direction & \multirow{3}{*}{ Dashboards } \\
\hline & $\begin{array}{l}\text { Financial exposure in relation to your other suppliers - Balance portfolio of supplier } \\
\text { spent }\end{array}$ & \\
\hline & large Budget vs Actual variances & \\
\hline & Project funding not according to Operational blueprint & 118 \\
\hline & Strategic misalignment of projects & D18 \\
\hline & Not using a supplier portfolio to spread exposure & Int. 6 \\
\hline \multirow{8}{*}{$\begin{array}{l}\text { Supplier's incompetent service } \\
\text { delivery }\end{array}$} & Supplier focus on one level (strategic, tactical or operational) only & $\begin{array}{l}\text { Strategic Alliance } \\
\text { MOU's }\end{array}$ \\
\hline & Supplier does not do Strategic level problem solving & T4 \\
\hline & Supplier has unresolved disputes with $3^{\text {rd }}$ parties & T17 \\
\hline & Supplier is unresponsiveness or incomplete RFP/RFI & 117 \\
\hline & Low service delivery capacity and sustainability & \multirow{2}{*}{ Absa PFS } \\
\hline & Supplier has deficient Skills \& Knowledge & \\
\hline & Supplier has poor capability to deliver service & Int. 3 \\
\hline & Supplier is developing poor IT solutions & 122 \\
\hline \multirow{2}{*}{$\begin{array}{l}\text { Supplier compromises its } \\
\text { integrity }\end{array}$} & Supplier behave unethically & Int.2 \\
\hline & Solicitation of staff & $\begin{array}{l}\text { Strategic Alliance } \\
\text { MOU's }\end{array}$ \\
\hline
\end{tabular}

